\title{
INTERNATIONAL FINANCIAL REPORTING STANDARDS: A REVIEW OF STATUS OF ADOPTION AND APPROACHES FOR EVALUATION
}

\author{
Habeeb Mohamed Nijam ${ }^{1, a^{*}}$, Athambawa Jahfer ${ }^{2, b}$ \\ 1,2 Department of Accountancy and Finance, Faculty of Management and Commerce, South \\ Eastern University of Sri Lanka, Oluvil, Sri Lanka \\ a Corresponding Email: nijamhm@seu.ac.lk \\ b Corresponding Email: jahfer@seu.ac.lk
}

\begin{abstract}
Keywords: IFRS, Accounting, Standards, Adoption, Impact, Evaluation, Approaches,
\end{abstract} Convergence, Harmonization, Status.

\begin{abstract}
The purpose of this review is to explore various approaches and perspectives that are currently being used by empirical studies reporting the impact of IFRS adoption in different jurisdictions around the globe. For this purpose to be better served, this study also presents at the outset an overview of the scope, objectives and current adoption status of IFRS. This study reviewed the literature on classifications of IFRS adoption studies with the view of deducting methodical frameworks outlining the dimensions that may warrant investigation for IFRS to be consented as a set of quality and global accounting standards. This study concludes that the success of IFRS as an international accounting standard depends on one hand in its technical quality economically yielding to both users and reporters of financial statements and on the other hand their acceptance across different jurisdictions despite their political, cultural and economic diversities.
\end{abstract}

\section{Introduction}

Business entities report general purpose financial statements providing spectrum of corporate financial information that are useful for various stakeholders. According to the IASB's conceptual framework for financial reporting, the objective of general purpose financial statements is to provide financial information for existing and potential investors, lenders and other creditors who provide resources to the entity. It is thus evident that the objective of financial statement is primarily erected on the concept of decision usefulness. Financial statements are hence expected to give true and fair view of the business. International Financial Reporting Standards (IFRS) thus lay down principles on recognition, measurement, presentation and disclosure thereby making financial reporting in a way that reflects economic reality and thus providing a true and fair view [1]. Majority of literatures on IFRS adoption thus concerns financial reporting quality and decision usefulness of financial statements when the impact of IFRS is sought to be studied.

Another vital dimension of corporate financial reporting is its comparability across firms [2]. Convergence to IFRS also aims to improve the comparability of financial statements across borders. Comparability of financial statements enables the users to compare the financial performance and position of a firm with that of other similar firms and of its own in the past. Prior to 2005, companies had adopted a variety of country-specific Generally Accepted Accounting Principles (GAAP) [3]. Convergence to international accounting standards has eliminated or significantly reduced the diversity in GAAP across different jurisdictions ${ }^{1}$. According to the Jurisdiction survey of IFRS foundation, 114 countries have adopted IFRS ${ }^{2}$. It is argued that there is little empirical evidence reporting the capital market effects of comparability of financial statement [4]. It may be

\footnotetext{
${ }^{1}$ Term "Jurisdiction" is generally used to refer a particular geographical area containing a defined legal authority. In the context of this paper it can be interpreted as a territory/country having a defined legal authority and the ability to choose its own system of accounting.

${ }^{2}$ Source: Analysis of the IFRS jurisdiction profiles published in website of IFRS Foundation and IASB as updated on 30 January 2015. They survey result has been summarized in the Table 01 below.
} 
supported with the argument that there prevails a significant variation in accounting quality and economic efficiency across countries [2]. This might be due to inherent differences in the economic, legal and enforcement environment in which firms operate.

Therefore, nevertheless many countries converge to IFRS there are also certain variation during the implementation of the IFRS system and it is therefore essential to have reliable evidence of the progress in the attainment of worldwide convergence [5]. The accounting and financial community are getting increasingly concerned in assessing the benefits associated with IFRS adoption [6]. Though corporate financial reporting can have many economic consequences, it is neither possible to reckon all of them nor all such effects have been well understood and supported by evidence [2]. It is therefore interesting to deduct key dimensions that warrant attention when we seek to evaluate international harmonization of financial reporting. This paper hence primarily attempts to review IFRS adoption studies with the view of deducting approaches or the dimensions that may warrant investigation for IFRS to be consented as a set of quality and global accounting standards. The remaining part of this review is organized in sections where the section two to follow captures the scope of IFRS. Subsequent other two sections would be committed to review the status of IFRS adoption and continuum of IFRS convergence respectively. Finally, the paper reviews and deducts the approaches being employed for IFRS impact evaluation.

\section{IFRS and their Scope}

According to the Preface issued to the IFRS, IFRS prescribe recognition, measurement, presentation and disclosure requirements dealing with transactions and events that are important in general purpose financial statements and other financial reporting of all profit-oriented entities. They include entities engaged in commercial, industrial, financial and similar activities, whether organized in corporate or in other forms inter alia mutual insurance companies and other mutual cooperative entities that provide dividends or other economic benefits directly and proportionately to their owners, members or participants. IFRS also apply to government business entities. Private sector or public sector or government entities involved in not-for-profit activities may still find IFRS appropriate though the IFRS are not designed to apply to them. However, there are customized international accounting standards for governments and other public sector entities. The International Public Sector Accounting Standards Board (IPSASB) prepares accounting standards for governments and other public sector entities, other than government business entities, based on IFRS. Though the objectives of the IASB in setting IFRS are given under four aspects, they can be augmented in Six Cs namely;

a) Common-Standards: The prime objective of the IASB is to develop, in the public interest, a single set of high quality, understandable and enforceable global accounting standards.

b) Credibility: IFRS lead to high quality and transparent information in financial statement.

c) Comparability: IFRS aim to enhance comparability of information reported in financial statements so that financial statements reported in different jurisdictions can effectively and widely be compared across borders.

d) Conformance: IASB attempts to promote the use and rigorous application of IFRS. This objective can be supported by the proposition that IFRS are principal based rather than rule based.

e) Customization: in fulfilling the above objectives IASB takes into account of, as appropriate, the special needs of small and medium-sized entities and emerging economies; and

f) Convergence: to bring about convergence of national accounting standards and IFRS to high quality solutions.

The arguments for a common set of standards for accounting and financial reporting of companies are attributed to the belief that they lead to improved financial reporting quality thereby enhanced usefulness, reliability, comparability and capital transaction efficiency effects of financial 
statements. IFRS are commonly stated as principle-based whereas domestic/local accounting standards are rule-based in most of the cases [7] [8]. Principles-based structure is necessary to provide sufficient flexibility to be applied on a global level [9]. Ijiri [7] also argues that under rule based accounting standards firms tend to manipulate accounting at the threshold of legal and illegal treatments. The principle-based system does not provide strict rule on dealing with specific circumstances but allows professional judgments. Under rule based systems accountants are required to exactly comply to the rules stipulated regardless of its contextual implications. GornikTomaszewski and Showerman [10] claim that such rules are exact guidelines that are provided for accountants to follow and they are often called as "bright-lines". Carmona and Trombetta [9] state that US GAAP is rule based due to that it provides rules that attempt to cover many scenarios including industry specific practices. Thus, the principles-based system allows professional judgment and contextual flexibility which there are often limited under rule based system.

\section{Status of IFRS Adoption}

Countries around the world are increasingly adopting IFRS directly or with necessary modification in order to get the financial statements of entities in its jurisdiction be widely accepted and compared globally. The vision of having global accounting standards is being publicly supported by 130 countries $^{3}$ around the globe and by many international organizations ${ }^{4}$. However, 10 jurisdictions out of 138 under profile survey of IFRS foundation, declined to make a public commitment supporting a single set of global accounting standards. They include Albania, Belize, Bermuda, Cayman Islands, Egypt, Macao, Paraguay, Suriname, Switzerland and Vietnam . Yet, even in the absence of a public statement on their commitment towards a single set of global accounting standards, IFRS are commonly used by publicly accountable entities (listed companies and financial institutions) in Belize, Bermuda, Cayman Islands, and Switzerland. According to the survey results of IFRS foundation as updated on 30 January 2015, 114 jurisdictions out of 138 surveyed ( 83 per cent of the total jurisdictions surveyed) have adopted the IFRS by requiring all or most domestic publicly accountable entities (listed companies and financial institutions) in their capital markets to comply IFRS. This also includes Colombia and Bhutan that have pledged to begin using IFRS respectively from 2015 and 2021.

Table 1: Status of IFRS Application in the World

\begin{tabular}{|c|c|c|c|c|}
\hline Region & $\begin{array}{l}\text { Jurisdictions } \\
\text { in the region }\end{array}$ & $\begin{array}{c}\text { Jurisdictions that } \\
\text { require IFRS for all } \\
\text { or most domestic } \\
\text { publicly accountable } \\
\text { entities }\end{array}$ & $\begin{array}{l}\text { Jurisdictions that permit } \\
\text { or require IFRS for at } \\
\text { least some (but not all or } \\
\begin{array}{c}\text { most) domestic publicly } \\
\text { accountable entities }\end{array}\end{array}$ & $\begin{array}{c}\begin{array}{c}\text { Jurisdictions that } \\
\text { neither require nor }\end{array} \\
\text { permit IFRS for any } \\
\text { domestic publicly } \\
\text { accountable entities }\end{array}$ \\
\hline Europe & 42 & 41 & 1 & 0 \\
\hline Africa & 20 & 16 & 1 & 3 \\
\hline Middle East & 7 & 6 & 1 & 0 \\
\hline Asia-Oceania & 32 & 24 & 3 & 5 \\
\hline Americas & 37 & 27 & 8 & 2 \\
\hline Totals & 138 & 114 & 14 & 10 \\
\hline As $\%$ of 138 & $100 \%$ & $83 \%$ & $10 \%$ & $7 \%$ \\
\hline
\end{tabular}

Source: Analysis of the IFRS jurisdiction profiles published in website of IFRS Foundation and IASB as updated on 30 January 2015.

\footnotetext{
${ }^{3}$ This statistics has been provided by Pacter [11] in his 'IFRS as global standards: a pocket guide' which reports the IFRS adoption status around the globe based on jurisdiction profile survey conducted by IFRS foundation. Pacter (2015) also reports that Combined GDP of IFRS jurisdictions is \$41 trillion which is more than half of the worldwide GDP. Though the European Union continues to be the single largest IFRS jurisdiction, the combined GDP of IFRS jurisdictions outside the $\mathrm{EU}$ (which is $\$ 24$ trillion ) is now greater than that of the EU itself ( which is US\$17 trillion)

${ }^{4}$ These international organizations include including the G20, World Bank, International Monitory Fund (IMF), Basel Committee, International Organization of Securities Commissions (IOSCO) and International Federation of Accountants (IFAC) as provided by IFRS Foundation in its official web page. [http://www.ifrs.org/use-around-theworld/pages/jurisdiction-profiles.aspx]
} 
Though it is a common wisdom/believe that IFRS leads to more advantages, there are yet many counter views that uniform standards will not be the right choice as the economic conditions underlying the economies drastically differ from country to country. Ball [6] observed that having uniform standards is one thing which is separate from achieving uniformity in practice due to the fact that most market and political forces are local, and will remain so for the foreseeable future. Thus, since it seems likely that there will be differences in the enforcement of accounting standards, from country to country, there will be no reason to expect that financial reports will be comparable from companies in different parts of the world. Therefore, during the past few years, financial reporting practices which were subject to radical changes all over the world have been at the center of many public policy debates. Covrig et al. [12] and Barth et al. [13] argue that IFRS improves the comparability of financial reports across countries thereby bringing greater efficiency to firms reporting across different jurisdictions. Opponents view includes inter alia that switching to IFRS is costly and the potential benefits of switching may not be realised due to disparities in the application of IFRS across countries [14 and 15]. Despite the opponent views on the adoption of IFRS, Sri Lanka with effect from $1^{\text {st }}$ of Jan 2012 has adopted IFRS on full scale convergence through its local accounting standards which are promulgated by the Institute of Chartered Accountants of Sri Lanka, the lawful body to adopt accounting standards in Sri Lanka time to time. In this backdrop, the impact of such gross adoption of IFRS into Sri Lankan economy give raise to a policy debate which needs to be empirically supported.

\section{Continuum of IFRS adoption}

From the approaches adopted on profile survey on IFRS adoption, the study observes that there are at least four important criteria (4ES) for a jurisdiction to be considered as to have adopted IFRS.

1. Enforceability: Application of IFRS in the jurisdiction is mandatory thereby legally enforceable. The accounting law or regulations in the jurisdiction is expected to mandate or require the adoption of IFRS directly or through domestic accounting standards that are modeled on IFRS. Just permitting entities to voluntarily adopt the accounting standards is not counted as the adoption of IFRS. E.g. Countries such as Bermuda, Cayman Islands, Guatemala, Honduras, India, Japan, Madagascar, Nicaragua, Panama, Paraguay, Suriname and Switzerland permit the application of IFRS but not mandating or requiring its adoption by domestic publicly accountable entities.

2. Engagement: IFRS or IFRS based domestic standards should be engaged by all or most domestic publicly accountable entities. That is, IFRS or the domestic standards modeled on IFRS should rule financial reporting of all or most of domestic publicly accountable entities. Mandating or permitting the adoption of the IFRS by a section of publicly accountable entities or unlisted companies has not been regarded as an adoption of IFRS. E.g. Even though Saudi Arabia and Uzbekistan require IFRS for unlisted financial institutions, it is not regarded as to have adopted IFRS.

3. Entirety: Adoption of selected IFRS is not considered to be an adoption of IFRS. Therefore the IFRS are to be adopted in its entirety. Very little modification and temporary deferment of application of certain accounting standards/ choices are still within the scope of adoption.

4. Elasticity: Domestic standards should be elastic enough to allow the adoption of significant changes brought in IFRS in future. Having static accounting standards that would not adopt or not permit the adoption of significant future developments in IFRS will not result in effective adoption of IFRS.

Through the review of the status of IFRS adoption around the world primarily based on the facts provided by IASB and IFRS foundation, it can be stated that domestic accounting standards of countries around the world are increasingly become ruled by IFRS. The IFRS is being adopted as national accounting standards with or without modifications by an increasing number of developing and transitional economies [16 and 17]. However, IFRS application may take different approaches which can be captured as below. 
a) Direct Reception; that is, having IFRS as domestic accounting standards: in this approach, a country shall declare/extent, by law or any regulations, the IFRS as their domestic accounting standard. Thus the changes in IFRS will be effective in the particular country from the date on which such changes were made in the IFRS. However, in practice this approach is not popular among countries at this stage of harmonization and may be expected upon a more integrated global economy in future.

b) Full Adoption; that is, having IFRS in domestic accounting standards: where the IFRS is fully adopted into the domestic accounting standards. This approach is contemporarily popular in the globe. Around 114countries have adopted IFRS.

c) Partial Adoption; where the IFRS is partially (not at its entirety) adopted into the domestic accounting standards or IFRS is made applicable to a section of publicly accountable entities (not all publicly accountable entities required IFRS based reporting).

d) Permission; that is, having IFRS and domestic accounting standards: where neither IFRS have been adopted or made compulsory into domestic financial reporting environment nor it is restricted to be adopted voluntarily. Governments under this option just permit the adoption of IFRS. This happens normally when the country is in transitional process into IFRS.

e) Substantial Convergence: that is, having IFRS alike domestic accounting standards:

IFRS foundation survey also reveals that there are 24 jurisdictions that have not adopted IFRS. These countries have adopted different approaches with respect to application of IFRS in their jurisdiction.

1. Permission to Apply ( No Mandatory Adoption): Twelve countries which include Bermuda, Cayman Islands, Guatemala, Honduras, India, Japan, Madagascar, Nicaragua, Panama, Paraguay, Suriname, Switzerland, permit the application of IFRS but not mandating its adoption by domestic publicly accountable entities.

2. Adoption of IFRS for Unlisted Firms: Two jurisdictions which include Saudi Arabia and Uzbekistan require IFRS for financial institutions but not listed companies.

3. In the Process of Full Adoption: Thailand is in process of adopting IFRS in full.

4. Substantial Convergence: Indonesia is in the process of converting its national accounting standards substantially (but not entirely) with IFRS.

5. Use of National or Regional Standards: Eight jurisdictions use national or regional standards: Bolivia, China, Egypt, Guinea-Bissau, Macao, Niger, United States, and Vietnam.

\section{Approaches for IFRS Impact Evaluation}

The increasing adoption of the IFRS by countries around the globe has prompted a number of studies which have examined the impact or usefulness or relevance or benefits by the adoption of these standards. Two decisions are important to make the IFRS inter alia as 'global accounting standards', which is also an objective of IASB in IFRS setting. One is whether the IFRS adoption is a 'net benefit' and the second is whether such benefit is prevalent regardless of political, economic and cultural diversities among countries that are expected to adopt IFRS. This perspective arises a question whether the net gain on IFRS adoption depends on whether the country in which the reporting firm/s operates is developed or developing etc. Paragraph 44 of Conceptual Framework for the Preparation and Presentation of Financial Statement holds that

.... The benefits derived from information should exceed the cost of providing it. The evaluation of benefits and costs is, however, substantially a judgemental process. Furthermore, the costs do not necessarily fall on those users who enjoy the benefits. Benefits may also be enjoyed by users other than those for whom the information is prepared; for example, the provision of further information to lenders 
may reduce the borrowing costs of an entity. For these reasons, it is difficult to apply a cost-benefit test in any particular case. Nevertheless, standard-setters in particular, as well as the preparers and users of financial statements, should be aware of this constraint.

It is therefore possible to group the IFRS implementation benefit into two major categories; the benefits to the users of the financial statement (user- benefit) and the benefits to the reporting entity (firm-benefit). Investors are the primary users of financial statement and they are said to benefit from IFRS by getting relevant information to make economic decisions. Yet, yielding of this benefit itself will not make IFRS widely accepted in long run unless the firm that incur cost of implementation thereof (both explicit and implicit costs) are at least tradeoff. Therefore, the attainment of both types of benefits (that is, user- benefit and firm-benefit) is important to realize the goals of IFRS.

Lambertides and Mazouz [18] also groups IFRS adoption studies into two main streams based on the benefits by the IFRS adoption where the first stream focuses on 'quality of information production' which may constitute to 'user- benefit' and second stream does on 'reduction of cost of capital' which tends to represents 'firm-benefit'. First stream of studies on IFRS adoption as described by Lambertides and Mazouz [18] investigate whether the IFRS adoption leads to higher quality of information disclosed to outside investors so that information are more relevant to their economic decision ( which is user- benefit). Lambertides and Mazouz [18] cite Harris et al. [19], Bartov et al. [20], Barth et al. [13] and Atwood et al. [21] as some relevant studies falling into first stream and claim that such studies show that the disclosure under internationally recognized standards provides higher information quality to outside investors than the local reporting regimes. According to Lambertides and Mazouz [18], the second stream of analytical research investigates whether the higher information quality under IFRS contributes to lower a firm's cost of capital (That is, firm-benefit) . Lambertides and Mazouz [18] also cite Coles et al. [22] and Diamond and Verrecchia [23] as some relevant studies falling into second stream and claim that firms with higher levels of disclosure convert a larger proportion of private information into public information. This, in turn, reduces information asymmetries among the different groups of investors, increases liquidity and lowers the cost of capital. IFRS studies that sought to investigate the impact on user -benefit have often employed the concepts of value relevance of accounting information, earning management, analysts' earnings forecast errors etc. to investigate whether financial statement and other information disclosed under IFRS based standards are more useful for the economic decision makings of investors, the prominent users of financial statement. The impact of IFRS implementation on benefit to the reporting firms may be judged in many ways which may include reduction of cost of capital, foreign capital inflow, increased value of firm, improved governance, good will creation etc.

The success of IFRS as an international accounting standard depends on its technical richness and acceptance across different countries despite political, cultural and economic diversities. Technically speaking, IFRS set out recognition, measurement, presentation and disclosure requirements dealing with transactions and events that are important in general purpose financial statements (Preface to IFRS). Recognition and measurement requirements of IFRS are directly related to 'accounting numbers' while presentation and disclosure requirements often relate to 'disclosers' that make the accounting information more relevant to decision making. IFRS's impact thus bears on two items of a financial statement which are 'accounting numbers' and 'disclosures'. Benefits of IFRS implementation can be related to users of financial statements primarily the investors and or the firms reporting on such standards. Users may benefit by the financial information reported in compliance with the IFRS in such a way as to get more reliable, comparable and more useful information for making their economic decisions.

Thus, the technical dimensions that the IFRS empirical studies focus can be summarized and depicted as in Figure 1. 


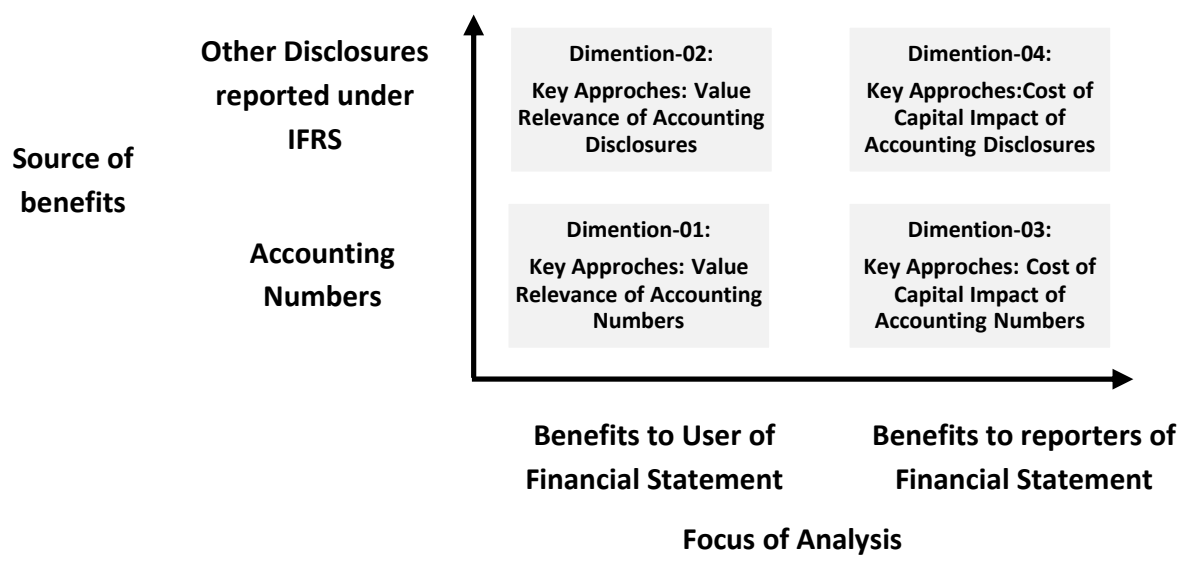

Figure 1: Four Technical Dimensions of IFRS Impact.

Source: Author.

Many studies have used the concept of value relevance of accounting information to view the impact of IFRS. Value relevance of accounting information indicates the extent to which the accounting information explain share price or stock return and thus firms' value. Besides, the concepts earning management/earning quality, precision of analysts' earnings forecast also have been extensively used for evaluating user's benefit by the implementation of IFRS. Kadri et al. [24], Karampinis and Hevas [25], Chalmers at al. [26], Chamisa et al. [16], Kargin [27] and Beisland and Knivsfla [28] are some examples of researches that have explored the impact of IFRS adoption through changes in value relevance of accounting numbers. Wang et al. [29], Tsalavoutas and Dionysiou [30] are some examples of studies falling in Dimention-02. They evaluate value relevance of disclosures (either or both voluntary and mandatory disclosures) in relation to IFRS implementation.

Besides, another perspective to view the IFRS impact builds on its internationality. If the IFRS are to be truly international accounting standards, the above impacts of IFRS must be evident in countries across the globe irrespective of political, economic and cultural diversities. Chamisa et al. [16] claim that there are two constituents of studies on the value relevance of IFRS depending on the economic context in which the data are obtained. That is, whether the data from developed, developing and transitional economies. This classification arises on the hypothesis whether the impact created by the IFRS adoption differ depending on economic context in which the firms operate. There may be differences of impact of IFRS adoption depending on whether the economy is of developed or developing category. Niskanen et al. [31 and 32] and Bartov et al. [20] are some studies anchored in developed economy while Jermakowicz and Gornik- Tomaszewski, [33], ElShamy and Al-Qenae, [34], El-Shamy and Kayed, [35] and Chamisa et al [16] are some investigations in developing countries.

It is therefore possible to view another four dimensions that analytical studies may focus. These dimensions view the acceptance of IFRS across different political, cultural and economic spheres. This study creates four such political dimensions based on two such parameters as 'Focus of Analysis' and 'Underlying Economy in which the reporting firm/s operate'. This can be presented in the matrix in Figure 2. 


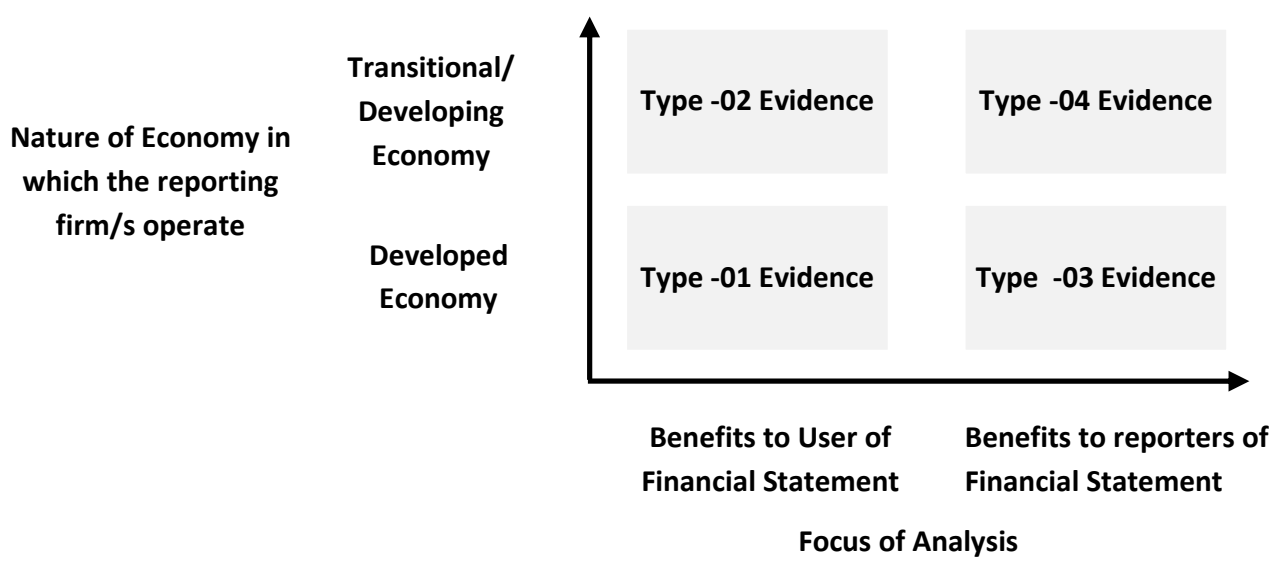

Figure 2: Four Political Dimensions of IFRS Impact.

Source: Author.

Therefore, the success of IFRS adoption and its sustainability as global accounting standards shall require four types of evidences to be established as illustrated above. Type -01 and Type -02 evidences here indicate that financial statements prepared under international financial reporting standards are found to be more decision relevant to the users of such financial statements respectively in developed and developing economies. Type -03 and Type -04 evidences are obtained when financial statements prepared under international financial reporting standards are found to be more advantageous to the firms reporting such financial statements respectively in developed and developing economies.

\section{Conclusion}

International Financial Reporting Standards (IFRS) are 'conventionally' believed to improve financial reporting quality and comparability. IFRS has been adopted by 114 jurisdictions by requiring all or most domestic publicly accountable entities in their capital markets to comply IFRS. IFRS adoption benefits that have focused by IFRS adoption studies may be broadly grouped into two major categories; the benefits to the users of the financial statement (user- benefit) and the benefits to the reporting entity (firm-benefit). User benefit itself will not make IFRS widely accepted in long run unless the firms that incur cost of IFRS implementation (both explicit and implicit costs) are at least tradeoff. Therefore, the attainment of both types of benefits (that is, userbenefit and firm-benefit) is important to realize the goals of IFRS and investigations to assess the impact of IFRS should thus be made accordingly. It is found that IFRS studies that sought to investigate the impact on user -benefit have often employed the concepts of value relevance of accounting information, earning management, analysts' earnings forecast errors etc to investigate whether financial statement and other information disclosed under IFRS based standards are more useful for the economic decision makings of investors, the prominent users of financial statement. This study observes that the impact of IFRS implementation on benefit to the reporting firms are being judged in many ways which may include reduction of cost of capital, foreign capital inflow, increased value of firm, improved governance, good will creation etc. Driven by these factors, this study captures eight broader types of technical and political dimensions that deserve investigations for assessing technical richness and international acceptance of IFRS. Based on the review in this study, this study concludes that the success of IFRS as an international accounting standard depends on one hand in its technical quality economically yielding to both uses and reporters of financial statements and on the other hand their acceptance across different jurisdictions despite their political, cultural and economic diversities. 


\section{Reference}

[1] True and Fair Accounting and Reporting, Financial Reporting Council, The Financial Reporting Council Limited, UK (2014).

[2] L.Hail, C. Leuz, P.Wysocki , Global Accounting Convergence and the Potential Adoption of IFRS by the U.S. (Part I): Conceptual Underpinnings and Economic Analysis, Accounting Horizons, 24(3) (2010) 355-394.

[3] N.Soderstrom, K. Sun, IFRS adoption and accounting quality: A review, European Accounting Review, 16 (2007) 675-702.

[4] G. De Franco, S. Kothari, R. Verdi.. The benefits of financial statement comparability. Working paper, 2009, MIT Sloan School of Management.

[5] N. Apergis, C. Christou, C. Hassapis, Accounting standards convergence dynamics International evidence from club convergence and clustering, Accounting Research Journal, Vol. 27(3) (2014) 1-33.

[6] R. Ball, International financial reporting standards (IFRS): pros and cons for investors, Accounting and Business Research, 36 (2006) 5-27.

[7] Y.Ijiri, US accounting standards and their environment: a dualistic study of their 75 years of transition, Journal of Accounting and Public Policy, 24(4) (2005) 255-79.

[8] B.Bennett, M.Bradbury, H.Prangnell, Rules, principles and judgments in accounting standards, Abacus,42(2) (2006) 189-204.

[9] S. Carmona, M.Trombetta, On the global acceptance of IAS/IFRS accounting standards: the logic and implications of the principles-based system, Journal of Accounting \& Public Policy, 27 (6) (2008) 455-461.

[10] S. Gornik-Tomaszewski, S.Showerman, IFRS in the United States: challenges and opportunities, Review of Business, 30 (2) (2010) 59-71.

[11] P. Packter, IFRS as global standards: a pocket guide, IFRS Foundation, (2015)

[12] V.M.Covrig, M.L. DeFond, M. Hung,.Home bias, foreign mutual fund holdings, and the voluntary adoption of international accounting standards, Journal of Accounting Research, 45(1) (2007) 41-70.

[13] M.E. Barth, W.R.Landsman, M.H.Lang, International accounting standards and accounting quality, Journal of Accounting Research, 46(3) (2008)467-98.

[14] S.Sunder, IFRS and the accounting consensus, Accounting Horizons, 23(1) (2009) 101-11.

[15] E.Kvaal, C.Nobes, International differences in IFRS policy choice: a research note, Accounting and Business Research,40(2) (2010) 173-87.

[16] E.Chamisa, M. Mangena, G. Ye, Relative value-relevance of accounting measures based on Chinese Accounting Standards and International Financial Reporting Standards, Journal of Accounting in Emerging Economies, 2(2) (2012) 162 - 187.

[17] D.Tyrrall, D.Woodwaed, A.Rakhimbekova, The relevance of International Financial Reporting Standards to a developing country: evidence from Kazakhstan, The International Journal of Accounting, 42(1) (2007) 82-110.

[18] N.Lambertides, K.Mazouz, Stock price volatility and informational efficiency following the mandatory adoption of IFRS in Europe, Journal of Applied Accounting Research, 14(1) (2013) $4-17$.

[19] T.S. Harris, M. Lang, H.P.Moller, The value relevance of German accounting measures: an empirical analysis, Journal of Accounting Research, 32(2) (1994)187-209.

[20] E. Bartov, S.R.Goldberg, M. Kim, Comparative value relevance among German, US, and international accounting standards: a German stock market perspective, Journal of Accounting, Auditing and Finance, 20(2) (2005) 95-119.

[21] T.J. Atwood, M.S.Srake, J.N.Myers,L.A.Myers, Do earnings reported under IFRS tell us more about future earnings and cash flows?, Journal of Accounting and Public Policy, 30(4) (2011) 103-21.

[22] J.Coles, U. Loewenstein, J.Suary, On equilibrium pricing under parameter uncertainty, Journal of Financial and Quantitative Analysis, 30(2) (1995) 347-64. 
[23] D.Diamond, R.E.Verrecchia,.Disclosure, liquidity, and the cost of capital, Journal of Finance, 46(4) (1991)1325-59.

[24] M.H.Kadri, R.A.Aziz, M.K.Ibrahim, Value relevance of book value and earnings:evidence from two different financial reporting regimes. Journal of Financial Reporting and Accounting, 7(1) (2009) 1- 16.

[25] N. I.Karampinis, D. L.Hevas,.Mandating IFRS in an unfavorable environment: The Greek experience, The International Journal of Accounting,46 (2011) 304-332.

[26] K.Chalmers, F.Navissi, W. Qu, Value relevance of accounting information in China pre- and post-2001 accounting reforms, Managerial Auditing Journal, 25(8) (2010) 792-813.

[27] S. Kargin, The impact of IFRS on the value relevance of accounting information: evidence from Turkish firms, International Journal of Economics and Finance, 5(4) (2013).

[28] L.A.Beisland, K.H.Knivsfla, Have IFRS changed how stock prices are associated with earnings and book values?, Review of Accounting and Finance,14(1) (2015) 41 - 63.

[29] Z.Wang, M.J. Ali, M.Al-Akra,. Value relevance of voluntary disclosure and the global financial crisis: evidence from China, Managerial Auditing Journal,28(5) (2013) 444 - 468.

[30] I.Tsalavoutas, D.Dionysiou, Value relevance of IFRS mandatory disclosure requirements, Journal of Applied Accounting Research, 15(1) (2014) 22 - 42.

[31] J.Niskanen, J.Kinnunen, E.Kasanen, The association of stock returns with international accounting standards earnings: evidence from the Finnish capital market, The International Journal of Accounting, 29(4) (1994) 283-96.

[32] J.Niskanen, J.Kinnunen, E.Kasanen, The value relevance of IAS reconciliation components: empirical evidence from Finland, Journal of International Financial Management and Accounting, 19(2) (2000)119-37.

[33] E.K.Jermakowicz, S. Gornik-Tomaszewski, Information content of earnings in the emerging capital market: evidence from the Warsaw stock exchange, Multinational Finance Journal, 2(4) (1998) 245-67.

[34] M.El Shamy, R. Al-Qenae, The change in the value relevance of earnings and book values in equity valuation over the past 20 years and the impact of the adoption of IASs: the case of Kuwait, International Journal of Accounting, Auditing and Performance Evaluation, 12(1/2) (2005) 153-67.

[35] M.A.El Shamy, M.A.Kayed, The value relevance of earnings and book values in equity valuation: an international perspective - the case of Kuwait, International Journal of Commerce and Management, 14(1) (2005) 68-79. 